\title{
CURRENT STATUS OF THE DENTAL PRACTICE IN BULGARIA. META-ANALYSIS
}

\author{
Lydia Katrova, Krassimir Tzokov \\ Department of Public health, Faculty of Dental Medicine, \\ Medical University - Sofia, Bulgaria
}

\section{ABSTRACT}

The purpose of this study was to show the leading trends in dental practice and dental profession development after two decades of transition.

Materials and methods: A systematic review of data was performed including analysis of secondary statistical data and benchmarking data from relevant publications.

Results: The meta-analysis found that: The dentists/ patients ratio decreased steadily; The dental surgeries' development, in terms of new equipment, is observed; The use of support staff increased from 1996 to 2001, and decreased as on 2011; The utilization of dental services, compared to EU level is going down; The disproportion between new technologies implementation and lack of trained support staff utilization was evidenced; Long-term trend toward general versus specialize care was demonstrated

Conclusions: The extensive growth and irregular distribution of dental practices, along with the decrease of the dental services' utilization shape the portrait of the dental profession and dental practice in Bulgaria by the end of the first decade of 21 century.

Key words: dental practice, dental practitioner, dental service utilization, dental staff, professional status

\section{INTRODUCTION}

The development of dentistry in Bulgaria in recent decades has led to major changes, such as: promotion of private ownership of health facilities, participation of the dental profession in the tripartite model $^{1}$ of social and health assurance, technological innovation of dental surgeries, marketization of the professional activities [3]. Dentists identify themselves as a regulated profession [4].

These changes are the result of processes occurring in society and in the professional community. On the other hand, they are the basis and the precursor of future development of the health care entities, the dental practices, in particular.

\footnotetext{
1 "Tripartite": Tripartite, with the participation of the State, the employees and the employers.
}

The review of the literature, as a part of the preparatory stage of a dissertation study entitled "Organization of the dental practice in market conditions", showed that the process of professionalization of dentists and the changes in the health care system were relatively well studied. As regards the development of dental practices, it was found that there is a lack of sufficient and reliable data to explain the complex socio-economic impacts on the professional and technological aspects of the of dental practices today. Therefore, with this study we focused on the search of relevant information to lighten this range of issues and define long-term trends in dental practices' development in Bulgaria by the first decade of the 21 century.

\section{PURPOSE}

The aim of this study was to present the current status of dental practices in Bulgaria as a result of 20 years' period of development (1990 - 2010), based on a systematic review of data. To support the hypothesis, the following tasks had been formulated:

1. To make a brief description of the demographic situation and demographic trends of Bulgarian population;

2. To present the demographic characteristics of practicing dentists in Bulgaria (distribution by sex and age) and their number and distribution all over the country;

3. To present the structure and the development of dental practices ${ }^{2}$.

\section{MATERIAL AND METHODS:}

The metha-analysis ${ }^{3}$ consists of comparative evaluation of data, issued from published to date studies. The literature review covers two periods: (1990-2000) and (2000-2010). Studies' review comprises: author, year, subject field, study period and sample size (Table 1).

${ }^{2}$ Change in status, change in type of practice, professional development of physicians, support staff development

${ }^{3}$ Meta-analysis is a quantitative method for combining data from independent studies with similar design, combined in a single measurement scale. In a meta-analysis of primary data from surveys again processed and analyzed in biostatistics: stratification, standardization, control errors, etc. In randomized studies, meta-analysis derive empirical results $[12,13]$. 
Comparison of empirical data extracted from publications was presented graphically. A secondary analysis of statistical data was performed. Used are official sources of statistics ${ }^{4}$.

Table 1: Review of literature

\begin{tabular}{|l|l|l|l|}
\hline Author / Year & Subject field (Key - words) & Period & Sample size \\
\hline L Katrova(2009) & Trends in dental demography & $1996-2008$ & $842,98,235$ \\
\hline L. Katrova(2009) & Mobility, continuity & $1983-2008$ & $\begin{array}{l}320,230,96,96 \\
\text { (students) }\end{array}$ \\
\hline L Katrova, Hr. Kisov(2009) & $\begin{array}{l}\text { Postgraduate education } \\
\text { Continuing education' courses }\end{array}$ & $1995-2009$ & $1551,93,235,135$ \\
\hline $\begin{array}{l}\text { L. Katrova P. Bojinov, } \\
\text { I. Mihailova.(2007) }\end{array}$ & Health reforms, Professional status & $1995-2005$ & $842,192,98$ \\
\hline Katrova L., et al.(2004) & Treatment' needs & $2000-2002$ & 130 (patients) \\
\hline $\begin{array}{l}\text { L. Katrova, } \\
\text { K. Tzokov(2001) }\end{array}$ & Professional statusAuxiliary staff & 1996 & 842 \\
& & 2001 & 192 \\
\hline $\begin{array}{l}\text { L. Katrova, } \\
\text { M. Grashkina(1999) }\end{array}$ & Utilization of dental service & 1999 & 400 (patients) \\
\hline L. Katrova(1997) & Dental health service, Personnel & $1986-1995$ & 1707 \\
\hline L. Katrova,(1995) & Profession's Reproduction Social Aspects & $1985-1995$ & 230 (students) \\
\hline
\end{tabular}

\section{RESULTS AND DISCUSSION}

1. Brief description of the demographic situation and demographic trends in Bulgaria

The latest census in Bulgaria (2010) stated the total number of the population at $7,364,570$ people [11]. Compared to previous moment, this figure confirms the trend of continuing decrease in number. In 2009 the total number of the population was 7,563,710 (about 200000 more) while in the year 2000 the total number was $8,149,468$ people (about 800000 more) [5].

This trend is characteristic for almost all regions of the country, excepted the regions of Varna, Sofia-city, where an increase in the number of the population is observed (Table 2) $[5,7]$.

Table 2: Change of number of the population by region

\begin{tabular}{|l|l|l|l|l|l|}
\hline \multicolumn{1}{|c|}{ Year } & $\mathbf{2 0 0 2}$ & $\mathbf{2 0 0 7}$ & $\mathbf{2 0 0 8}$ & $\mathbf{2 0 0 9}$ & $\mathbf{2 0 1 1}$ \\
\hline Begion & & & & & \\
\hline Varna & 421049 & 420095 & 420840 & 422319 & 415817 \\
\hline Vidin & $\mathbf{4 6 0 0 0 1}$ & 459613 & 463260 & 465465 & $\mathbf{4 7 5 0 7 4}$ \\
\hline Kardjali & 125158 & 112604 & 110310 & 108067 & 101018 \\
\hline Plovdiv & 162332 & 156652 & 156008 & 154719 & 152808 \\
\hline Rousse & 712702 & 705121 & 704057 & 701684 & 683027 \\
\hline Sofia-city & $\mathbf{1 1 9 4 1 6 4}$ & 1240788 & 1247059 & 1249798 & $\mathbf{1 2 9 1 5 9 1}$ \\
\hline Targovishte & 139600 & 132771 & 131233 & 129675 & 120818 \\
\hline Shumen & 201890 & 196559 & 195479 & 194090 & 180528 \\
\hline
\end{tabular}

${ }^{4}$ National Health Information Center (NHIC), National Statistical Institute (NSI) and registers of Bulgarian Dental Association (BgDA). 
The distribution by sex and age of the population shows a sustainable tendency to aging. The number of women prevails excepted in younger age groups where a slight increase of male population is observed. Excess of women is generally due to the higher life expectation of women (Fig.1), [11].

Fig 1. Population by age and sex groups.

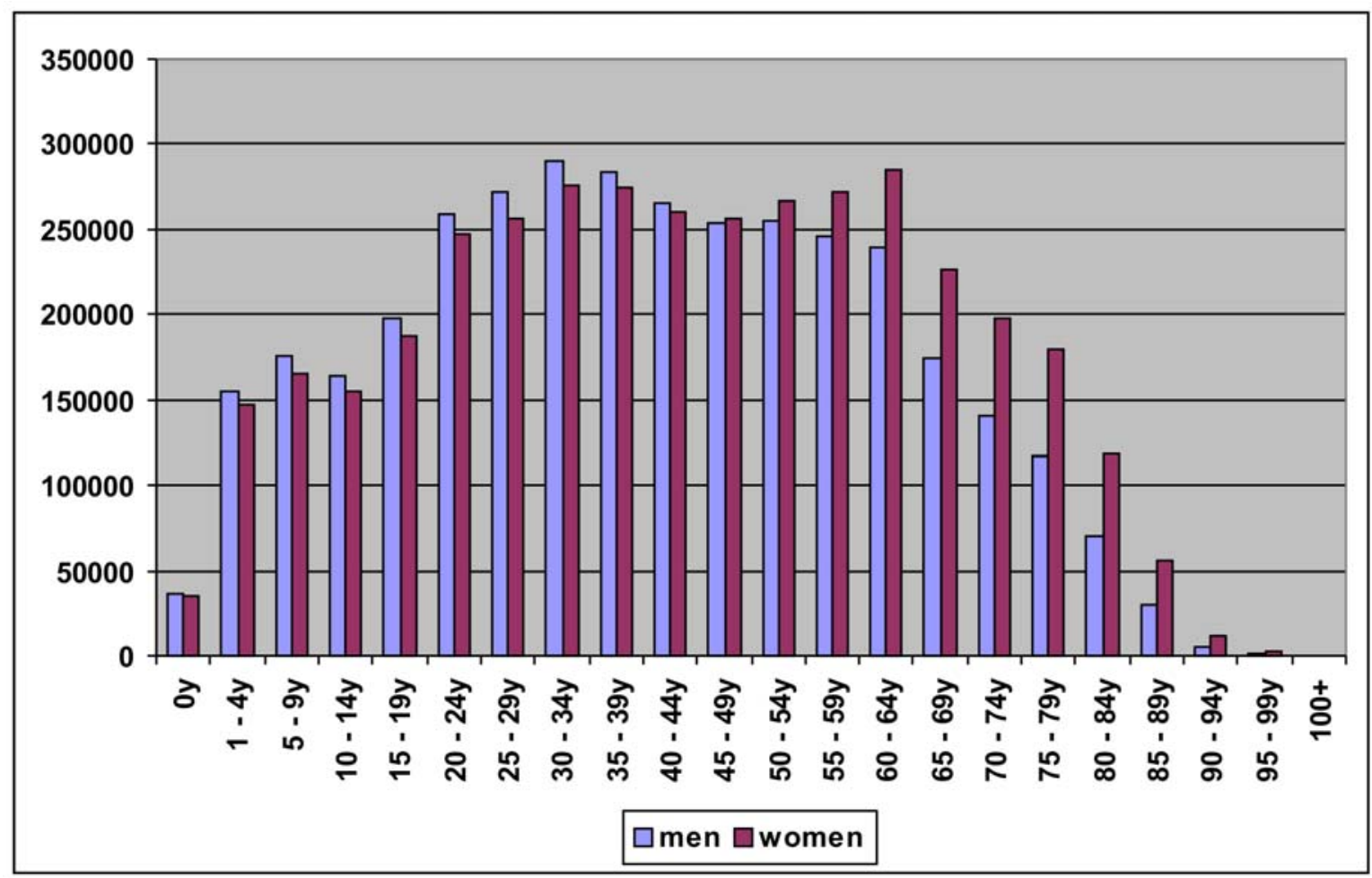

\section{Professional demographics of dentists}

The number of dentists in Bulgaria for the studied period increased considerably. Data published by the Bulgarian Dental Association (BgDA) and those published by the National Health Information Center (NHIC) show some differences, so we present them in parallel (Table 3.), $[5,1]$.

Table 3: Number of dentists by region

\begin{tabular}{|l|l|l|l|l|l|l|}
\hline \multirow{2}{*}{ Region/ source } & \multicolumn{3}{|c|}{ NHIC } & \multicolumn{3}{c|}{ BgDA } \\
\cline { 2 - 7 } & $\mathbf{2 0 0 8}$ & $\mathbf{2 0 0 9}$ & $\mathbf{2 0 1 1}$ & $\mathbf{2 0 0 8}$ & $\mathbf{2 0 0 9}$ & $\mathbf{2 0 1 1}$ \\
\hline Bourgas & 258 & 272 & - & 340 & 369 & 383 \\
\hline Varna & 378 & 426 & - & 471 & 486 & 486 \\
\hline Vidin & 96 & 108 & - & 125 & 113 & 109 \\
\hline Kardjali & 104 & 115 & - & 128 & 133 & 135 \\
\hline Plovdiv & 862 & 936 & - & 1028 & 1172 & 1226 \\
\hline Rousse & 162 & 162 & - & 186 & 190 & 198 \\
\hline Sofia-city & 1545 & 1479 & - & 2265 & 2449 & 2400 \\
\hline
\end{tabular}




\begin{tabular}{|l|l|l|l|l|l|l|}
\hline Targovishte & 59 & 62 & - & 72 & 66 & 68 \\
\hline Shumen & 99 & 105 & - & 112 & 112 & 116 \\
\hline
\end{tabular}

The case of Sofia is very significant. According to $\mathrm{BgDA}$ data the number of dentists in Sofia-city changes from 1545 people in 2000 to 2,449 in 2009. According to NHIC data the number of dentists in the city of Sofia ranged from 1781 (in 2000) to 1479 (in 2009), ( Fig 2.).

Fig. 2. Parallel records of the changing number of dentists, the case of Sofia-city

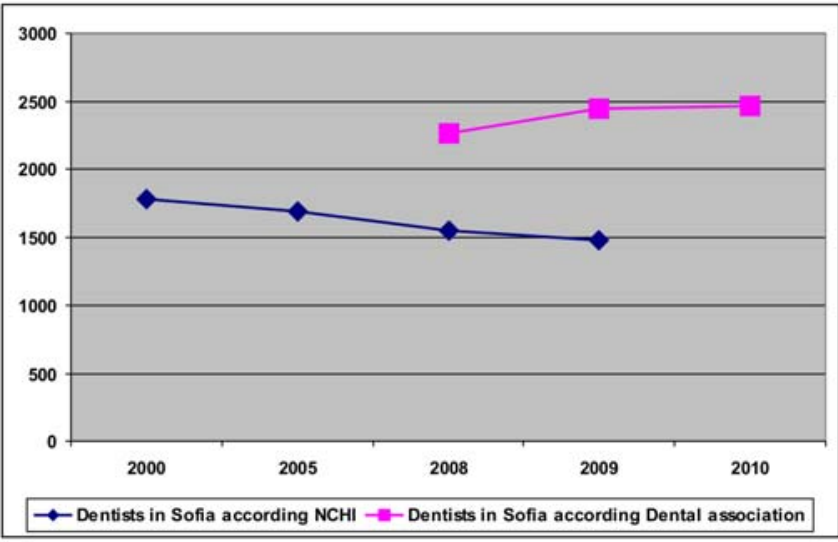

We consider that the discrepancies in the data from two citied sources could be due to the different methods of registration. The BgDA keeps the dental practitioners' register. The reduced number issued from this register is reflecting the increasing trend towards working abroad and/ or aging of the professional group. On the other hand, the Regional Health Centers register the dental practices. Sometimes one practitioner could be registered more than once, because he/she may practice at more than one place. $\mathrm{He}$ or she may be owner of more than one practice and /or employees other dentists to work with him/her or for him/her. Actually in the first case the figures correspond to the number of doctors, while in the second case the figures correspond to the number of dental practices (hospitals).

Age-sex structure of dentists' population is modified as follows:

From a total of about 8000 dentists registered in 2010 (source $\mathrm{BgDA}$ ) about $66 \%$ are women, while in 1990 female dentists represented $75 \%$ of the total number of active practitioners. With regard to changes in age composition there two opposing trends are observed: for the country as a whole and for Sofia City, (Fig. 3), [9].
Fig. 3. Differences in men:women dentists ratio and average age of dentists in Sofia and the country

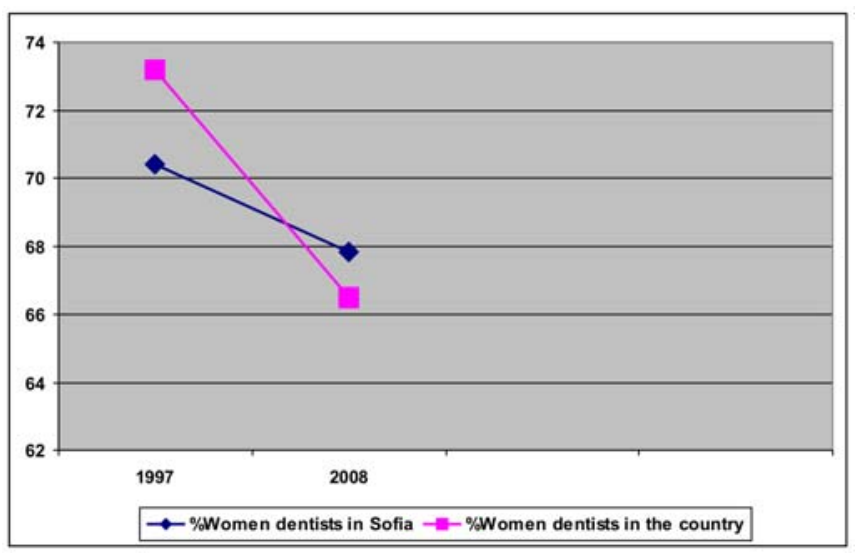

Fig.3a. Men:women dentists ratio

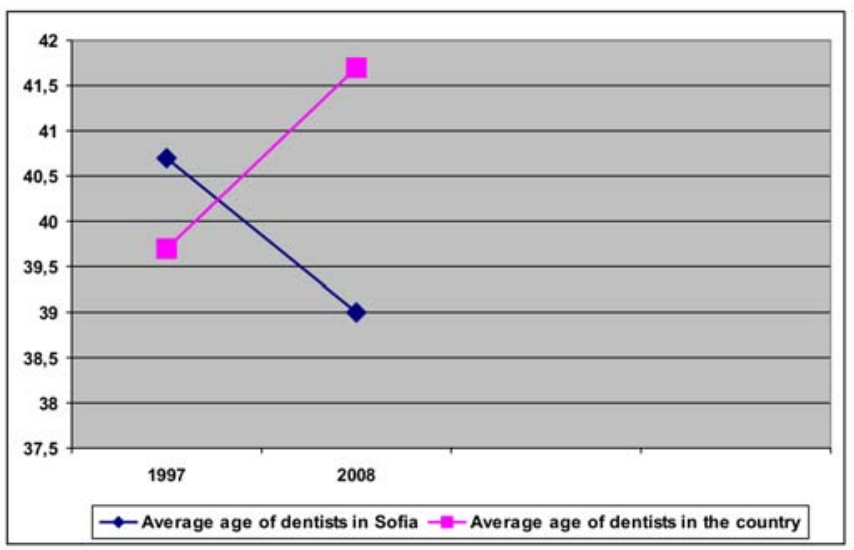

Fig.3b. Average age differences

While the average age of dentists for the country as a whole is growing - from 39.7 years in 1997 to 41.7 years in 2008, for the Sofia - city it demonstrates an opposite trend: from 40.7 years in 1997 to 39.0 years to 2008 . This result is due to the fact that Sofia is a university town and newly graduate dentists widely registered for practice in Sofia.

The distribution of dentists is uneven over the country. The number of dentists in urban centers grow: in Varna (from 381 dentists in 2000 to 426 dentists in 2009), in Plovdiv (from 785 dentists in 2000 to 936 dentists in 2009), in Pernik (from 112 dentists in 2000 to 136 dentists in 2009),[3].

In more densely populated regions, characterized by relatively highly developed economy the number of practices is higher and more dentists are registered, while in less 
developed regions the number of practices and practitioners is less. On one hand, better infrastructure in places like city of Sofia, Varna, Plovdiv, Pernik, provides easy access to the dental practices, on the other, higher level of employment results in a higher income for the population and consequently bigger purchase power of the population, (Fig. 4).

Fig 4. Dentists : patients ratio per regions

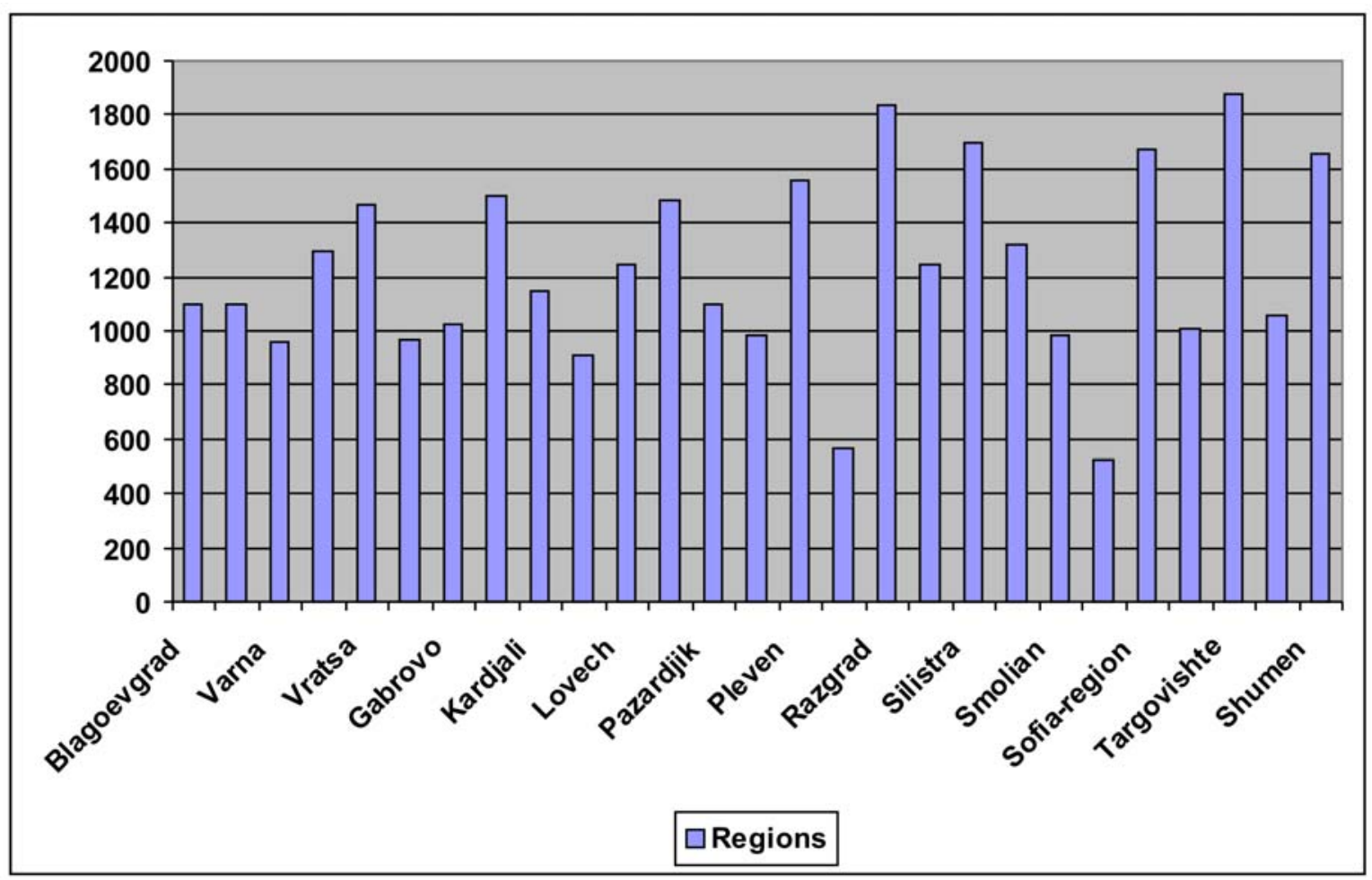

Comparing the demographic trends among the population with the extensive development of infrastructure and the growing number of dental practitioners, it is obvious that the number of patients treated by a doctor is permanently getting reduced (Fig. 5). (3),

Fig. 5. Impact of the demographic changes of the population on patients:dentists ratio for the period (1980 2009.)

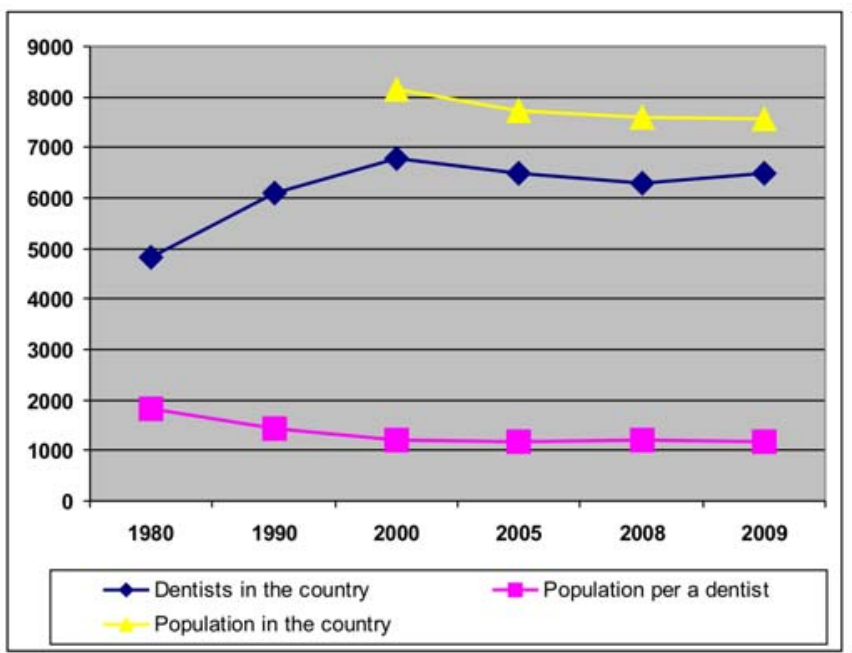


3. Structure and development of dental practices

The parameters studied were: change in status, change in type of practice, professional development, auxiliary staff development, improvement of equipment. According to literature data for the period 1991-2001 the status of dentists was irreversibly transformed by employees in the health care system in freelance practitioners. The percentage of general practitioners increases at the expense of the number of specialists. The number of specialists and specializing is going down. At the same time, the system for continuous postgraduate education is advancing under the guidance of the $\mathrm{BgDA}$ as well as private educational entities.

Working with auxilliary staff constitutes a small percentage of practices. The data show that after an increase of the share of dental practices working with auxlliary staff during the period 1996 - 2000, a period of stagnation followed $(2000-2005)$ at the level of $40 \%$ and a sharp reduction in staff utilization was demonstrated (2005 2009). The similar is the trend when studying the process of auxilliary staff training (Fig.6) [8].

\section{practices}

Fig.6. Dental auxilliary utilization in dental

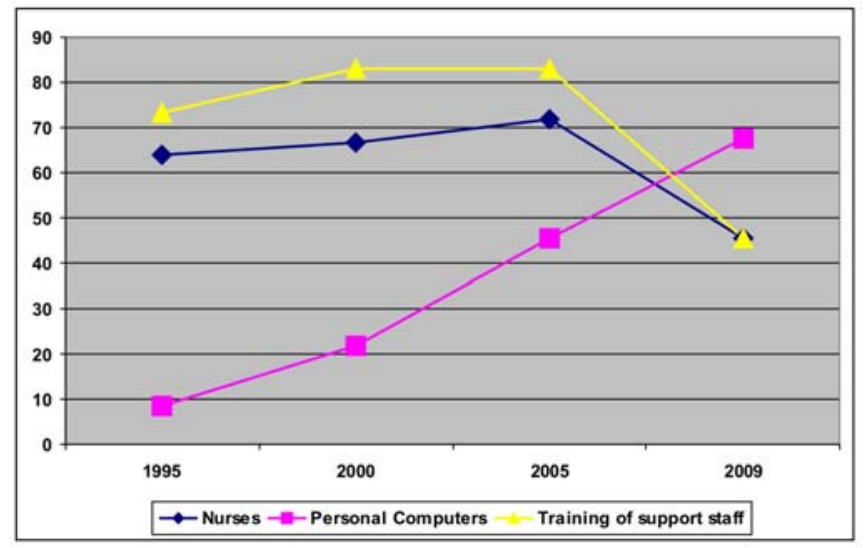

There is a gradual renewal of dental equipment at the expense of imported equipment (from 16.6\% for 1996, to $17.7 \%$ for 1999 and $24.0 \%$ for 2001 ). At the same time the tendency for using over 10 years old dental equipment is still present (1996 - 61.2\%, $1999-58.2 \%, 2001-70.6 \%)$. Slowly but steadily percentage of practices working with implant systems is growing $(1996-4.1 \%, 1999-4.2 \%, 2001-$ $6.4 \%$ ). Most demonstrative is the increase of number of practices using personal computers (Fig.7), (8).
Fig.7 Technological development of dental practices

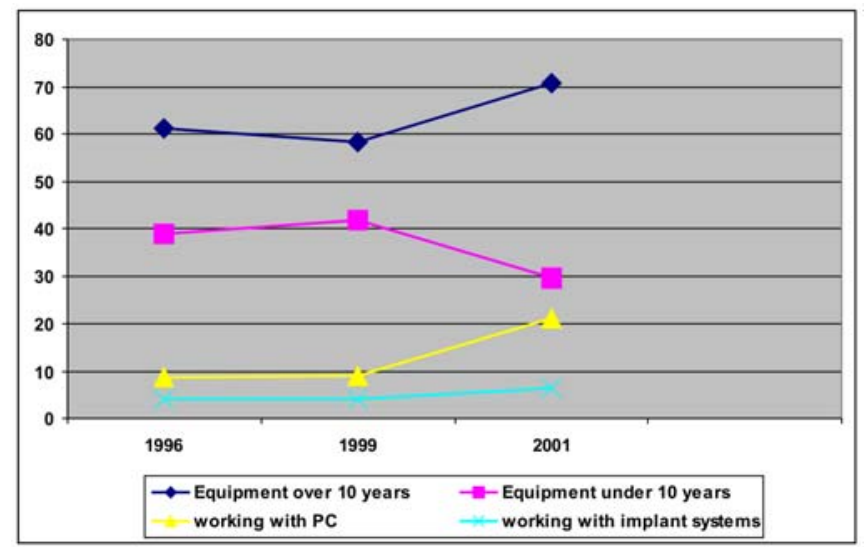

\section{Discussion:}

Sustainable reduction in the number of the population and its uneven distribution over the country is due to social factors rather than to demographic conditions. The most attractive areas for the population are those with lower unemployment rate and better conditions for living, such as: Sofia city, Varna, Burgas, Plovdiv, as well as destinations abroad. Internal and external migration contribute significant depopulation of other regions like Vidin, Targovishte.

Overall, the number of dentists is growing, but we can not expect the demand for dental care to increase due to financial restraints for consumers. As a result, migration of the population is followed by migration of dentists in relatively same direction - from small villages to large agglomerations and / or outside of the country. Defeminization of the profession is a lasting trend, as more highly expressed in the country as a whole and less on the territory of Sofia -city. Rejuvenation of the profession is typical for the region of Sofia, but not for the country as a whole, where an increase in the average age of active practitioners of dental medicine is observed.

Dental practices are characterized by a clear trend towards technological innovation, while retaining the gap between the technology and team development. Surplus of technological innovation, training and equipment without taking account of available specialists and their implementation, and ignoring the problems of dental team will rise new challenges for dentists to develop their practices.

Mobility of the profession and patients will determine the new parameters of dental practice. Economic situation of the population's health literacy and education will play an increasingly important market impact. 


\section{CONCLUSIONS:}

1. The dental practice' development should be studied in the context of the processes of European integration and globalization and the existing socio-economic conditions in Bulgaria.

2. The sample should include regions and municipalities that represent the structure of the population and the dental profession nationwide.

3. Methodologies for collecting and publishing data from various sources should be critically studied in the course of the study.

\section{REFERENCES:}

1. Статистически данни от регистьр на БЗС за 2011 г. (in Bulgarian) http:// www.bzs.bg/site/index.php?option $=$ com content $\&$ task $=$ view $\&$ id $=964 \&$ Itemid $=663$

2. Special eurobarometer oral health 330. http://ec.europa.eu/public_opinion/ archives/ebs/ebs_330_en.pdf

3 Катрова Л. Стоматологичната професия - състояние и перспективи. Leading technology in dentistry София, 1998, 290 c, ISBN 954-90363-1-6. (in Bulgarian)

4. Катрова Л. Цоков Кр. Катрова Цв. Промяната на социално - професионалния статус на стоматолозите в България в хода на здравната реформа. Годишен сборник ИМАБ. 2002; 8(1):18-21. (in Bulgarian)

5. Национален център по здравна информация, здравна статистика http:// www.nchi.government.bg/ http:// www.nchi.government.bg/Eng/Engli6.html. (in Bulgarian)

6. Катрова Л, Хр. Кисов. Ученето през целия живот - задължение или привилегия за лекаря по дентална медицина, продължаващото следдипломно образование - задължение или привилегия за факултетите по дентална медицина. Проблеми на денталната медицина, XXXVI, 2010, №2, c.28-36, ISSN: 03239403. (in Bulgarian)

7. Катрова Л, Папанчев Г. и др. Удовлетворяване на потребностите от лечение на кариеса и неговите усложнения в условията на здравно осигуряване, Проблеми на стоматологията, том XXX/2004, с. 63-68, ISSN 0323-9403. (in Bulgarian)

8. Катрова, Л. Професионално-демографски аспекти на структурната реформа в стоматологията Стоматол. преглед, т. 29, 1998, №2, c. 11-28. (in Bulgarian)

9. Катрова Л, М. Грашкина. Използваемост на стоматологичната здравна служба в преходния период. (1999-2000), Проблеми на стоматологията т. 27, 2000 с. 115-125, ISSN 0323-9403. (in Bulgarian)

10. Катрова Л. Генерационна мобил- ност в зъболекарската професия, приемственост и перспективи Soc. Med. Sofia, 17, 2009, No 3, c. 29-32, ISSN: 1310-1757. (in Bulgarian)

11. http://www.nsi.bg/census2011/ indexen.php

12. Ранчов Г. Биостатистика и биоматематика: концепции, методи, приложения. София, 2008 ISBN: 978-95491084-9-1. (in Bulgarian)

13. Шипковенска Е., Методология на научно-изследователската работа, Здравна политика и мениджмънт, 2011, том 11, №1, ISSN 1313-4981. (in Bulgarian)

14. Katrova L. Leading trends in dental profession demography in Bulgaria for the period 1996-2008 (OP112). 14th Congress of BASS, 9th Scientific Congress of the BgDA. 6-9 May 2009 Varna.

15. Katrova LP. Bojinov I. Mihailova. Oral Health Care reforms in Bulgaria during the period of transition. Oral health and Dental Management in the Black Sea Countries, 2007, Vol. VI, No 4, pp 3-8

\section{Corresponding author:}

Lydia Katrova

Department of Public health, Faculty of Dental Medicine, Sofia

1, Georgi Sofiiski Str. 1431 Sofia, Bulgaria.

tel: $+359 / 29541230,+359 / 888569742$,

E-mail: Lydia_katrova@yahoo.com 